\title{
ANALISIS PESAN MORAL DALAM FILM JANGAN BACA PANCASILA KARYA RAFDI AKBAR
}

\author{
Dani Manesah ${ }^{1}$, Rosta $_{\text {Minawati }}^{2}$, Nursyirwan ${ }^{3}$ \\ ${ }^{1}$ Pascasarjana Institut Seni Indonesia Padangpanjang \\ ${ }^{2}$ Institut Seni Indonesia Padangpanjang \\ ${ }^{3}$ Intitut Seni Indonesia Padangpanjang \\ manesahh@gmail.com
}

\begin{abstract}
ABSTRAK
Penelitian ini berjudul Analisis Pesan Moral Dalam Film Jangan Baca Pancasila.Film jangan baca pancasila mengisahkan tentang sebuah keluarga yang mempunyai seorang anak yang bernama Sandy, Sandy tumbuh dan besar seperti pada umumnya, namun Sandy adalah seorang yang mengidap Asperger Syndrome, atau lebih dikenal dengan Autis, yang menyebabkan sulitnya ia dalam berkomunikasi dan berinteraksi sosial dalam lingkungannya, sejak ia kecil dia selalu dianggap aneh dan bodoh oleh banyak orang, hanya karena sikap autisnya tersebut.Tulisan ini bertujuan dalam menemukan pesan moral yang terdapat dalam film Jangan baca pancasila menggunakan sebuah teori semiotika Roland Barthes.Metode penelitian Roland Barthes peneliti gunakan dalam memecahkan pesan moral yang terkandung pada scene dalam film Jangan baca pancasila yang diambil dengan mendenotasikan pesan serta makna konotasi yang ada pada film Jangan baca pancasila. Adapun hasil analisis pesan moral yang terdapat dalam film Jangan baca pancasila karya Rafdi Akbar dalam penelitian ini ditampilkan kedalam realita yang sesungguhnya yaitu dengan adanya hubungan manusia dengan manusia, adanya hubungan manusia dengan sang pencipta dan adanya hubungan manusia dengan lingkungan.
\end{abstract}

Kata Kunci : Autis, Denotasi, Konotasi, Semiotika, Roland Barthes.

\section{ABSTRACT}

This study is entitled Analysis of Moral Messages in Movies Don't Read Pancasila. Films do not read Pancasila tells about a family who has a child named Sandy, Sandy grows and grows up as usual, but Sandy is a person with Asperger Syndrome, or better known as Autism, which makes it difficult for him to communicate and interact socially in his environment, since he was a child he was always considered strange and stupid by many people, just because of his autistic attitude. This paper aims to find the moral message contained in the film. Do not read the Pancasila using a Roland Barthes semiotics theory. The research method of Roland Barthes researchers uses in solving the moral messages contained in the scene in the film. on film Don't read Pancasila. As for the results of the analysis of moral messages contained in the film Do not read the Pancasila by Rafdi Akbar in this study shown in the real reality of the existence of human relations with humans, the existence of human relations with the creator and the existence of human relations with the environment.

Keywords: Autism, Denotation, Connotation, Semiotics, Roland Barthes.

\section{PENDAHULUAN}

Film merupakan sebuah alat dalam hal penyampaian berbagai pesan kepada masyarakat dengan menggunakan media cerita. Film juga merupakan alat sebagai media ekpresi artistik bagi para pekerjanya baik seniman maupun insan yang bekerja dalam dunia 
perfilman dan mampu mengutarakan gagasan ataupun ide-ide ke dalam sebuah cerita. Menurut Vera Film merupakan sebuah media komunikasi massa karena bentuk komunikator dan komunikan secara menyeluruh dalam artian berjumlah banyak dan tersebar dimana-mana dan menimbulkan efek tertentu. Film juga mencerminkan kebudayaan terhadap suatu bangsa dan dapat mempengaruhi kebudayaan nya sendiri [10]. Sejak kemunculan pertama kalinya film sudah menjadi fenomena yang sangat menarik serta banyak diminati oleh masyarakat. Film juga memiliki kombinasi antara bahasa audio dan bahasa visual. Hal ini dapat didengar dan diterima oleh masyarakat serta orang-orang yang menontonya. Hal tersebut merupakan sebuah alur suatu proses peristiwa dan bentuk keadaan yang diamati dan dinilai melalui kacamata ilmiah atau melalui disiplin ilmu tertentu.

Film dapat mengikat penontonnya secara emosional serta memiliki kekuatan yang besar dalam segi estetika.Banyak orang yang menilai dan mengkritik film sebagai hiburan untuk pelarian dirinya. Namun ada juga orang yang memujinya kedalam sebuah bentuk seni yang imajinatif dan mengizinkan orang sadar akan mimpi dan fantasi mereka. Film sebagai alat media komunikasi massa memiliki peran yang sangat penting sebagai alat dalam menyampaikan pesan-pesan bagi yang melihatnya. Pesan-pesan tersebut dapat membawa dampak positif maupun negatif.Masyarakat dapat menangkap serta mengambil sebuah pesan dari film itu dengan mudah, akan tetapi terdapat juga yang kesulitan dalam menangkap pesan tersebut, terlebih lagi jika yang menonton dan melihat hanya dengan maksud hiburan saja. Masih banyak orang yang mengkritik penganalisis sebuah film disebabkan menurut mereka hal tersebut tidak berguna dan film kurang dinikmati. Tidak ada yang salah, karena pada setiap individu memiliki hak untuk memilih dan menentukan bagaimana ia akan memproses sebuah film, salah satunya adalah dengan menikmati dan melihat film namun tersebut, dan serius menangkap makna pesan yang ada di balik film. Hal tersebut salah ketika seseorang mengatakan dengan menganalisis sebuah film, seseorang tidak dapat menikmati film itu sama sekali. Seandainya seseorang mau dan ingin mencoba memahami dan menginterpretasikan sebuah film, dan membuka pikiran, maka film dapat memberikan informasi, mengedukasi bahkan menginspirasi.

Menurut Effendy film dalam bukunya kamus komunikasi. Menjelaskan bahwa media yang bersifat visual dan audio visual untuk menyampaikan pesan kepada sekelompok orang yang berkumpul di suatu tempat.hal tersebut terlihat jelas bagaiman seseorang dituntut berkreatifitas dalam kemajuan bidang teknologi [2] Kemajuan teknologi yang semakin hari semakin maju dalam duni ini membuat sebagian besar orang lebih kreatif dalam berbagai bidang, mulai dari bidang teknologi seni dan masih banyak lagi. Hal tersebut diakibatkan gencarnya antara arus komunikasi dan informasi.Dimana salah satunya adalah media komunikasi masa yang banyak diminati oleh semua kalangan masyarakat baik itu orang tua, muda, dewasa, dan anak-anak. Film bukanlah hal yang tabu lagi dalam kehidupan masyrakat, selain memiliki fungsi untuk member pengetahuan, dan informasi yang ada didalamnya.Menurut Irawanto. Menyebutkan bahwa Film selalu merekam realitas yang tumbuh dan berkembang dalam masyarakat, dan kemudian memproyeksikan ke atas layar. Meskipun pada awalnya film adalah hiburan bagi kelas bawah di perkotaan, dengan cepat film mampu menembus batas-batas- kelas dan menjangkau kelas yang lebih luas. Kemampuan film menjangkau banyak segmen sosial, kemudian menyadarkan para ahli bahwa film memiliki potensi untuk memperngaruhi khalayaknya.[3]

Salah satu pesan yang terkandung dalam film yaitu pesan moral.Pesan moral yang disampaikan lewat sarana komunikasi terdapat banyak jenisnya. Salah satunya adalah melalui media film yang bersifat komprehensif bagi masyarakat. Film adalah karya estetika dan alat informasi yang dapat menghibur dan dijadikan sebagai sarana edukasi bagi 
penikmatnya. Menurut Lillie, kata moral berasal dari kata morunles ataupun bahasa latin. Kata moral selalu mengarah kepada baik buruknya manusia dengan manusia sehingga dalam segi pandangan, moral merupakan pandangan hidup manusia dan di lihat dari bentuk kebaikannya sebagai seorang manusia. Norma-norma moral sebagai tolak ukur yang digunakan masyarakat dalam mengukur kebaikan seseorang.Magnis Suseno mengatakan bahwa sikap moral sebenarnya adalah moralitas.ia memberi pegertian bahwa moralias merupakan sikap hati seseorang yang ditampilkan dalam tindakan lahiriah. Moralitas terjadi ketika seseorang mengambil sikap baik dan ia sadar akan kewajiban dan tanggung jawabnya tersebut, bukan karena mencari keuntungan [4] sehingga moralitas merupakan sikap perbuatan baik dan betul-betul tanpa pamrih.Pengertian moral mengacu pada alasan mengapa sebuah tindakan itu dilakukan, sehingga dapat dinilai apakah tindakan itu baik ataupun buruk.Kohlberg tidak memusatkan perhatian pada pernyataan apakah tindakan itu benar ataupun salah. Dikarenakan orang dewasa dengan seorang anak kecil mungkin akan mengatakan sesuatu yang sama, maka di sini terlihat adanya perbedaan antara orang dewasa dan anak kecil. Apa yang membedakan dalam kematangan moral merupakan pada pengertian terhadap suatu hal yan benar ataupun salah. Dengan demikian pengertian moral bukanlah tentang sesuatu yang baik ataupun buruk, akan tetapi bagaimana seseorang berpikir sampai kepada sebuah keputusan bahwa yang baik ataupun buruk.[1]

Dalam hal lain penyebarluasan akan nilai-nilai budaya baru. Moral merupakan suatu hal sangat penting akan kehidupan manusia. Sebab seseorang bermoral akan selalu berbuat baik untuk dirinya sendiri maupun orang lain. Orang yang mempunyai moral tidak akanpernah dapat membohongi dan mengelabuhi kebenaran dan berani dalam memberantas pelanggaran. Mereka tidak akan lunak dengan rayuan atau suapan. Mereka yang bermoral akan senantiasa menghormati dan menghargai orang lain betapapun rendahnya kedudukan orang tersebut. Mereka juga senantiasa akan memberi contoh yang baik dalam setiap menjalankan aktifitas dalam kehidupannya. Untuk hal itu moral merupakan suatu hal yang sangat penting bagi kehidupan umat manusia [6]. Etika maupun moral sangat penting di dalam kehidupan sehari-hari. Etika enurut Kamus Besar Bahasa Indonesia (Departemen P dan K, 1988). Dibedakan menjadi beberapa macam diantaranya adalah :

1. Sebuah ilmu mengenai tentang apa yang baik dan apa yang buruk dan tentang hak dan kewajiban moral (akhlak);

2. Himpunan asas ataupun nilai-nilai yang berkenaan dengan akhlak.

3. Sebuah nilai mengenai benar dan salah yang dianut suatu golongan atau masyarakat.

Selain etika moral juga sangat diperlukan dalam kehidupan kita Nilai-nilai moral itu berada dalam suatu wadah yang disebut moralitas, karena di dalamnya terdapat unsurunsur keyakinan dan sikap batin dan bukan hanya sekadar penyesuaian diri dengan aturan dari luar diri manusia.Film merupakan produk karya seni dan budaya yang memiliki nilai guna karena bertujuan memberikan hiburan dan kepuasan batin bagi penonton. Melalui sarana cerita itu, penonton secara tidak langsung dapat belajar merasakan dan menghayati berbagai permasalahan kehidupan yang sengaja ditawarkan pengarang sehingga produk karya seni dan budaya dapat membuat penonton menjadi manusia yang lebih arif dan dapat memanusiakan manusia [7].

Sebagai hasil karya yang sangat unik dan menarik, film dapat menuangkan gagasannya kedalam bentuk gambar hidup, dan disajikan sebagai hiburan yang layak dinikmati oleh masyarakat. Dalam membuat sebuah film, film harus memiliki daya tarik tersendiri, sehingga pesan moral yang akan disampaikan bisa ditangkap oleh 
penonton. Film secara umum terbagi kedalam dua buah unsur yaitu unsur naratif dan unsur sinematik.unsur tersebut saling berinteraksi dan saling berkesinambungan antara satu sama lain dalam membuat sebuah film. Masing-masing unsur tersebut tidak akan dapat membentuk sebuah film jika hanya berdiri sendiri.Film dibagi menjadi sebuah unsur-unsur, yaitu shot,dan sekuen. Pemahaman mengenaishot ataupun adegan ini,akan berguna dalam hal membagi urutan-urutan (segmentasi) plot pada sebuah film secara sistematik. Segmentasi plot banyak membantu dalam hal melihat perkembangan plot kedalam sebuah film secara menyeluruh dari awal sampai akhir. Mise-en-scene: merupakan sesuatu hal yang terdapat didepan kamera kemudian akan diambil gambarnya dalam proses produksi film, berasal dari bahasa perancis yang memiliki arti "putting in the scene". Hampir seluruh gambar yang kita lihat dalam film adalah bagian dari unsur mise-enscene. Mise-enscene memiliki empat aspek utama yakni setting atau latar, kostum dan make up (tata rias meliputi wajah dan efek khusus), lighting atau tata cahaya, serta pemain dan pergerakannya [15]

Kehadiran film merupakan respon terhadappenemuan padawaktu luang dan di luar jam kerja serta jawaban terhadap kebutuhan dan menikmati waktu senggang secara hemat dan sehat bagi anggota keluarga.Sehingga dengan demikian, jika ditinjau dari segi perkembangan fenomenanya terbukti bahwa peran yang dimainkan dalam filmakan memenuhi kebutuhan tersembunyi sangat besar [5].Film jangan baca pancasila dengan merupakan film yang bergenre drama, Film Jangan Baca Pancasila menceritakan tentang sebuah keluarga yang memiliki seorang anakn laki-laki yang bernama Sandy, Sandy seorang pengidap Asperger Syndrome atau lebih dikenal Autis. Yang menyebabkan sulitnya ia dalam hal interaksi sosial. Dari kecil, ia selalu dianggap aneh dan bodoh oleh banyak orang, hanya karena sikap autisnya tersebut. Setelah dewasa, ia akhirnya menjadi mahasiswa salah satu universitas di kota nya. Di kampus, ia juga dianggap aneh dan bodoh oleh banyak orang hanya karena ia tidak mampu membaca kata-kata pancasila yang menurutnya susah untuk diucapkan. Karena anak autis, susah untuk mencerna kata-kata bermakna seperti itu.

Di kampus itu juga ia bertemu dengan Kevin, pemuda kristen yang akhirnya menjadi sahabatnya. Juga Citra gadis tomboi yang disukainya. Kevin bisa mengerti dengan sikap dan cara pandang Sandy yang autis. Suatu ketika, saat ada pengumuman pemilihan presiden mahasiswa, Sandy bertekad untuk ikut ambil bagian.Dan tentu saja Kevin mendukung sahabatnya itu. Saat tim Sandy melakukan kampanye untuk memilih Sandy, Kevin tertimpa duka yang mendalam. Ibunya meninggal.Hal itu membuat Kevin beberapa waktu harus meninggalkan Sandy.Sandy yang selama ini bergantung pada Kevin, merasa bingung dan panik.Ia dipermalukan Aldo, pesaingnya dalam debat pemilihan presiden mahasiswa. Ia disuruh membaca pancasila. Beberapa orang awalnya menganggap Sandy tidak mampu menjadi pemimpin.Membaca pancasila saja, dia tidak bisa.Itu kata mereka.

Namun saat artikel yang dibuat oleh Andre (Wartawan kampus), yang selama ini diam-diam meliput sikap dan perbuatan Sandy yang mencerminkan nilai-nilai pancasila meskipun tidak mau membacanya. Karena Sandy tidak mau hanya membaca, namun ia melakukannya. Semua orang berbalik mendukung Sandy.Hingga akhirnya Sandy berhasil terpilih menjadi presma. Di depan banyak orang, di depan ibu nya yang juga hadir, Sandy berpidato. Ia menjelaskan bahwa dia hanya autis, bukan aneh atau bodoh. Ia berbeda, semua orang berbeda. Namun bukankah perbedaan itu adalah warna yang menjadikannya indah? Dalam pidatonya ia juga mengutarakan perasaan sayangnya kepada ibunya yang selama ini ia ungkapkan lewat tulisan di buku kecilnya. Dan dengan polosnya ia mengatakan perasaanya kepada Citra lewat pidatonya tersebut. Di akhir cerita, Sandy menjadi sarjana, menikah dengan Citra dan menjadi seorang ayah. Sandy merampungkan buku yang ditulisnya tentang autisme.Autis merupakan gangguan perkembangan 
neuronologis yang sangat komplesk/berat dalam kehidupan yang panjang, meliputi gangguan pada aspek interasksi social, komunikasi dan bahasa dan perilaku serta gangguan emosi dan persepsi sensori bahkan pada aspek motoriknya . Gejala autis muncul pada usia sebelum 3 tahun [16].

Sedangkan pandangan Priyatna menyatakan bahwa autism mengacu pada problem dengan interaksi sosial, komunikasi dan bermain dengan imajinatif yang mulai muncul sejak anak berusia di bawah tiga tahun dan mereka mempunyai keterbatasan pada level aktifitas dan interest dan hamper tujuh puluh lima persen dari anak autispun mengalami beberapa derajat retardasi mental. Autisme juga merupakan sebuah gejala yang kompleks, karena kelainan pada anak autism seringkali tidak hanya terjadi pada satu bagian, namun meliputi banyak factor [11]

\subsection{Semiotika Roland Barthes.}

Secara umum semiotika merupakan sebuah kajian mengenai tanda dan bagaimana cara tanda-tanda tersebut bekerja dalam pengaplikasiannya. Kriyanto mengatakan bahwa semiotika merupakan studi tentang tanda dan segala yang berhubungan dengannya, cara fungsinya, hubungannya dengan tanda-tanda lain, pengirimannya dari penerimaan oleh mereka yang menggunakannya [13]

Semiologi ataupun semiotika hendak mempelajari bagaimana kemanusiaan memaknai hal-hal. Memaknai berarti bahwa objek-objek tidak hanya membawa informasi, dalam hal mana objek-objek itu hendak berkomunikasi, tetapi juga mengkonstitusi sistem terstruktur dari tanda. Dengan demikian melihat signifikasi sebagai sebuah proses yang total dengan suatu susunan yang sudah terstruktur. Signifikasi tak terbatas pada bahasa, tetapi juga pada hal-hal lain diluar bahasa. Barthes menganggap kehidupan sosial, apapun bentuknya, merupakan suatu sistem tanda tersendiri [7] . Film umumnya dibangun dengan banyak tanda, point penting dalam sebuah film adalah gambar dan suara. Film memberikan cerita dengan cara nya sendiri dan cara pengerjaannya dengan kamera hingga dipertunjukkan dengan sebuah proyektor dan layar ketengah-tengah masyarakat yang melihatnya.

Secara harfiah teori semiotika Roland Barthes diturunkan melalui teori bahasa menurut de Saussure. Roland Barthes mengungkapkan bahwa bahasa merupakan sebuah sistem tanda yang mencerminkan asumsi-asumsi dari masyarakat tertentu dalam waktu tertentu [14]. Selanjutnya, Barthes (1957, dalam de Saussure, yang dikutip Sartini) menggunakan teori signifikasi yang dikembangkan menjadi teori tentang metabahasa dan konotasi. Istilah signifikasi menjadi ekspresi dan signifie menjadi isi. Namun, Barthes mengatakan bahwa antara ekspresi menjadi isi harus ada relasi tertentu, sehingga membentuk tanda baru, sehingga membentuk tanda.

Konsep relasi ini membuat teori tentang tanda lebih mungkin berkembang karena relasi ditetapkan oleh pemakai tanda. Menurut Barthes, ekspresi dapat berkembang dan membentuk tanda baru sehingga ada lebih dari satu dengan isi yang sama. Pengembangan ini disebut sebagai gejala metabahasa dan membentuk apa yang disebut kesinambungan yang disebut kesinoniman.

Sebagaimana pandangan Saussure, Barthes juga meyakini bahwa hubungan antara penanda dan pertanda tidak terbentuk secara alamiah, melainkan bersifat arbiter. Bila Saussure hanya menekankan pada penandaan dalam denotatif, maka Roland Barthes menyempurnakan semiologi Saussure dengan mengembangkan sistem penandaan pada tingkat konotatif. Barthes juga melihat aspek lain dari penandaan, yaitu "mitos" yang menandai suatu masyarakat. 


\begin{tabular}{|l|l|l|}
\hline Sigifier & Signified & \\
\hline (Penanda) & (Petanda) & \\
\hline CONNOTATIVE SIGNIFIRE & CONNOTATIVE SIGNIFIED \\
\hline (PENANDA KONOTATIF) & (PETANDA KONOTATIF) \\
\hline \multicolumn{2}{|l}{ CONNOTATIVE SIGN (TANDA KONOTATIF) } \\
\hline
\end{tabular}

Gambar 2. Peta Tanda Roland Barthes.

Sumber : Paul Cobley \& Litzza Jansz. 1999. Introducing Semiotics. NY: Totem Books, hlm 51.

Dari peta Barthes diatas terlihat bahwa tanda denotatif menggunakan relasi antara penanda dan petanda.Akan tetapi, pada saat bersamaan, tanda denotatif adalah juga penanda konotatif.Jadi, tanda konotatif tidak hanya sekedar memiliki makna tambahan namun juga mengandung kedua bagian tanda denotatif yang melandasi keberadaanya.

Tanda yang terdapat pada film Jangan baca pancasila karya Rafdi Akbar akan dibahas menggunakan analisis semiotika. Hal ini dikarenakan metode semiotika mampu untuk menjelaskan hal-hal yang nampak dipermukaan semiotika juga mampu membongkar makna yang tersembunyi sehingga kedalaman dan keluasan informasi menentukan sejauh mana informasi itu diperoleh.

1.2. Mitos pada pandangan Barthes berbeda dengan konsep mitos dalam arti umum. Barthes mengatakan bahwa mitos adalah bahasa, maka mitos adalah sebuah sistem komunikasi dan mitos adalah sebuah pesan. Sementara mitos yang berkembang ditengah masyarakat merupakan sebuah kepercayaan akan hal-hal yang masih berbau mistis dan percaya terhadap benda-benda dan pohon-pohon besar. Dalam uraiannya Barthes mengemukakan bahwa mitos dalam pengertian khusus ini merupakan perkembangan dari konotasi. Konotasi yang sudah terbentuk lama dimasyarakat itulah mitos [7].

Dalam pengertian ini mitos tidak dipahami seperti pengertian biasa, akan tetapi dipahami sebagai sebuah proses pemaknaan itu sendiri.dalam ruang lingkup ataupun penjelasan semiotika itu sendiri. Mitos adalah sebuah cerita untuk digunakan pada suatu budaya dalam memahami sebuah aspek alam atau realitas itu sendiri.

Konotasi merupakan sebuah makna dari tahap kedua antara petanda maka mitos adalah sebuah makna pada tahap kedua dari petanda.pada gambar dibawah ini terdapat jenis pemodelan dua tahap signifikasi yang dapat dilihat pada gambar 2.

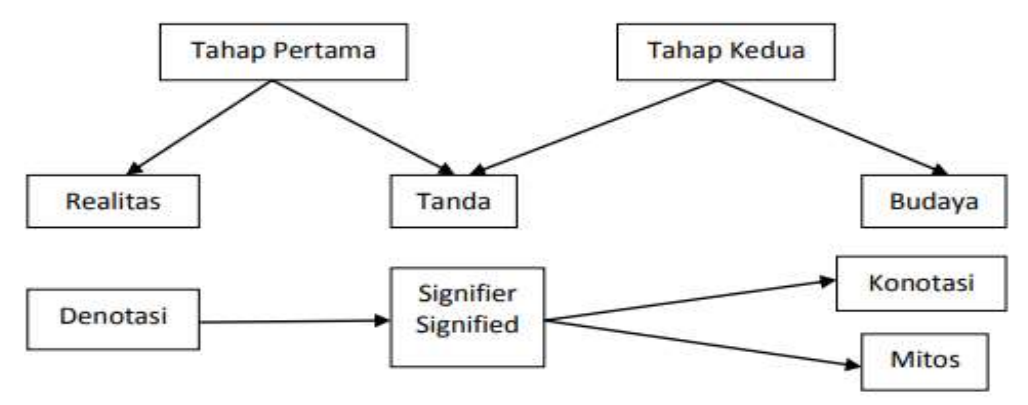

Gambar 2.Pemodelan dua Tahap Signifikasi Roland Barthes. Sumber : John Fiske, 1990. Introduction 
Pada gambar 2 tersebut menjelaskan mengenai proses Signifikasi dari tahap pertama yang merupakan hubungan antara signifier dan signified dalam sebuah tanda terhadap realitas eksternal yang ada. Barthes menyebutnya sebagai denotasi, merupakan makna paling nyata dari sebuah tanda.Konotasi adalah istilah yang digunakan Barthes dalam menunjukkan sebuah signifikasi dari tahap dua.Hal ini menggambarkan adanya sebuah interaksi yang terjadi ketika tanda bertemu dengan perasaan ataupun esensi dari seorang pembaca serta nilai-nilai kebudayaannya.

Terdapat beberapa alasan mengapa peneliti lebih memilih film ini untuk dianalisis dan diteliti dikarenakan, pada film jangan baca pancasila terdapat sebuah inspirasi dan terdapat sebuah nilai pesan moral seperti nilai religi, rasa hormat terhadap sesama dan rasa tanggung jawab ditampilkan kepada pemuda yang dapat memahami nilainilai pancasila.

Dalam penelitian ini penulis menggunakan metode penelitian kualitatif terdapat data pada penelitian ini bedasarkan peristiwa yang terjadi secara ilmiah. Menurut Bog dan Taylor berpendapat bahwa metodologi penelitian kulitatif sebagai prosedur penelitian yang menampilkan data deskriptif dan berupa kata-kata tertulis atau lisan dari orangdan prilaku yang dapat diamati. Dengan demikian sumber-sumber data dapat diperoleh dari wawancara, sumber tertulis. Foto, audio dan visual, serta data-data statistik.

Moeloeng mengikhtisarkan alasan metologis bagi penggunaan pengamatan ialah : penagamatan mengoptimalkan kemampuan peneliti dari segi motif, kepercayaan , perhatian, perilaku tak sadar, kebiasaan dan sebagainya; pengamatan memungkinkan pengamat untuk melihat dunia sebagaimana yang dilihat oleh subjek penelitian, menangkap arti fenomena dari segi pengertian subjek ; pengamat memungkinkan peneliti merasakan apa yang dirasakan dan dihayati oleh subjek sehingga memungkinkan pula sebagai peneliti menjadi sumber data; pengamatan memungkinkan pembentukan pengetahuan yang diketahui bersama, baik dari pihaknya maupun subjek [12]. Penelitian yang bersifat kualitatif memungkinkan tidak hanya mampu mengidentifikasi pesan-pesan manifest, melainkan juga latent messages dari sebuah dokumen yang diteliti. Jenis penelitian yang digunakan adalah deskriptif kualitatif, yaitu metode penelitian yang berusaha menggambarkan atau melukiskan objek yang diteliti berdasarkan fakta yang ada dilapangan.

Teknik analisis data yang terdapat padapenelitian ini merupakan sebuah upaya yang akan dilakukan bekerja dengandata, mengorganisasikan sebuah data, dan memilihmemilahnya menjadi satuan yang dapat dikelola. Mencari dan menemukan sebuah pola, apa yang penting dan apa yang akan dipelajari, serta memutuskan apa yang akan diceritakan terhadap orang lain. Data kualitatif dapat berupa kata, kalimat, dan narasi. Tahapan analisis data sangat penting dalam sebuah riset kualitatif, sebagai faktor utama penilaian kualitas terhadap riset. Kemampuan periset memberi makna kepada data merupakan sebuah kunci apakah data yang diperoleh memenuhi unsur reliabilitas data validitas atau tidak.

Teknik pengumpulan data dalam penelitian ini menggunakan beberapa cara yaitu: Dokumentasi yaitu menonton film Jangan Baca Pancasil Karya Rafdi Akbar adapun cara untuk mengidentifikasi simbol-simbol yang mewakili adanya bentuk moral disampaikan berupa audio maupun berupa visual.

Secara lebih khusus, ringkasan mengenai langkah-langkah yang akandianalisis dan diolah oleh semiotika. Adapun pengertian pada peta tanda Roland Barthes adalah sebagai berikut : 
1. Signifier ( penanda), bunyi yang bermakna ataupun coretan yang mempunyai makna. Sehingga penanda merupakan sebuah aspek material dari sebuah bahasa apa yang dikatakan ataupun didengar apa yang ditulis ataupun apa yang dibaca.

2. Signified ( Petanda), pada konsep ini makna muncul ketika adanya hubungan yang bersifat asosiasi yang akan ditandai ( signified ) dan yang akan menandai ( signifier ).

3. Denotative Sign ( Tanda Denotatatif ) kesatuan dari suatu bentuk penanda ( signifier ) sebuah ide atau penanda ( signified ). adalah gambaran mental, pikiran, dan konsep.

4. Connotative Signifier (Penanda Konotatif) tanpa adanya petanda tidak akanberarti apa-apa oleh karena itu sebaliknyapetanda tidak mungkin disampaikan atau ditangkap lepas dari penanda, pada petanda atau yang ditandakan termasuk tanda sendiri merupakan faktor linguistik.

5. Connotative Signified (Petanda Konotatif) Penanda dan petanda adalah sebuah kesatuan antara dua sisi dari selembar kertas sehingga pada dasarnya semiology ataupun semiotikamempelajari bagaimana kemanusiaan (humanity) memaknai sebuah hal (things). Memaknai (to signify) hal ini tidak dapat dicampuradukkan dengan mengkomunikasikan (to communicate).

6. Connotative Sign (Tanda Konotatif) Merupakan sebuah objek tidak hanya membawa sebuah informasi dari objekyang hendak dikomunikasikan,akan tetapi menyusun sebuahsystem yang terstruktur dari sebuah tanda.

Cara kerja atau logika analisis data ini sesungguhnya sama dengan kebanyakan analisis data kuantitatif. Peneliti memulai analisisnya dengan menggunakan kategorikategori tertentu, mengklasifikasikan data tersebut dengan adanya hubungan kriteriakriteria tertentu serta melakukan prediksi dengan teknik analisis yangtertentu pula.Secara lebih jelas, alur analisis dengan menggunakan Teknik Content Analysis terdapat pada gambar dibwah ini.

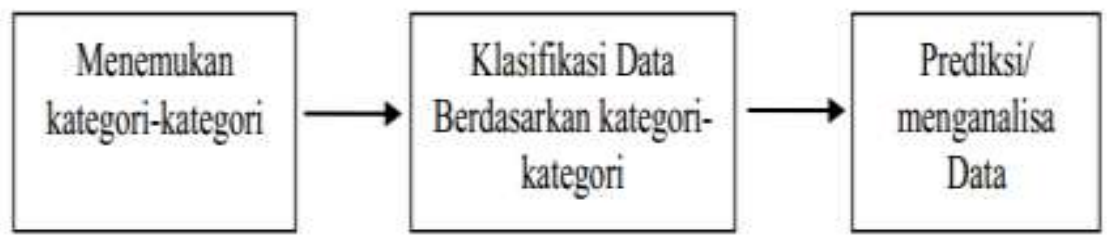

Gambar 3.Teknik Content Analysis

\section{STUDI LITERATUR}

Beberapa referensi penulisan dirujuk oleh peneliti dalam tulisan ini adalah sebagai berikut.

1. JOM FISIP Vol. 4 No. 1- Februari 2017 "Representasi Pesan Moral Dalam Film Rudy Habibie Karya Hanung Bramantyo ("Analisis Semiotika Roland Barthes") dalam jurnal ini membahas tentang pesan moral dalam film Rudy Habibie yang representasikan kemudian menghasilkan pesan moral seperti hubungan manusia dengan manusia, hubungan manusia dengan tuhan, serta hubungan manusia dengan lingkungan sosial.

2. Rokhyah Skripsi "Pesan Moral Membentuk Keluarga Sakinah Dalam Film "Habiebi dan Ainun "Karya Faozan Rizal", 2015. Dalam penlitian ini membahas pesan moral yang disampaikan Faozan Rizal dalam film Habibie dan Ainun untuk membentuk keluarga sakinah. Sedangkan obyek dalam penelitian ini yaitu penelitian pada film Habibie dan Ainun.

3. Ishmatun Nisa Skripsi “Analisis Pesan Moral Pada Film Jokowi” . penelitian yang dilakukan oleh Ishmatun Nisa yaitu menganalisis pesan-pesan moral yang terdapat 
dalam film Jokowi menggunakan teori semiotika Charles Sanders Pierce, kesimpulan ataupun hasil yag terdapat dalam penelitian ini yaitu menjelaskan adanya sifat sifat toleransi, adanya hubungan kepada Tuhan, berbakti kepada kedua orang tua, bersyukur, tolong menolong, dan sebagainya. Scene tersebut mengandung pesanpesan moral yang dapat dicontoh untuk anak-anak agar tertanam pada diri mereka tentang sifat-sifat moral yang mulia.

4. Vera Nawiroh. 2014. Semiotika dalam Riset Komunikasi. Bogor: Penerbit Ghalia Indonesia.

5. Andri Priyatna. 2010.Amazing Autism. Jakarta: Penerbit PT. Elex Media Komputindo.

6. eJournal, Volume 2, Nomor 2, 2014 "Representasi Analisis Semiotik Pesan Moral Dalam Film 2012 Karya Roland Emrich

\section{PEMBAHASAN}

Jangan baca pancasila merupakan sebuah film yang bercerita tentang sebuah keluarga yang memiliki seorang anak yang bernama Sandy. Sandy lahir seperti pada anak pada umumnya, penyakit Asperger Syndrome yang diderita nya sejak kecil, membuat dia susah untuk berkomunikasi atau pun bersosialisasi kepada masyarakat dan lingkungannya, tak jarang orangorang sering menyebutnya aneh. Sandy hidup dan besar dengan seorang Ibu yang merawatnya dengan penuh kesabaran hingga dia besar.Pertama kali Sandy mengenal lingkungan dan bersosialisasi, ketika ibu nya mengantarkan Sandy ke kampus, namun perlakuan teman-teman sandy ibunyamemberikan semangat kepada Sandy, ketika pihak kampus mengadakan pemilihan presma, dengan keterbatasan yang dimiliki nya, Sandy pun berniat ikut dalam pemilihan presma, hingga Sandy memenangkan perlombaan tersebut.

Teori semiotika Roland Barthes yang penelitigunakan untuk penelitian ini, yaitu mengambil beberapa point dari sebuah adegan film itu dalam menentukan petanda dan penanda serta makna pesan moral yang ada dalam film Jangan baca pancasila. Pengambilan scene pada menit ke 27 lewat 58 detik ini menggunakan teknik medium close up. Teknik medium close up digunakan untuk menunjukkan bahwa sedang berlangsungnya percakapan normal antara tokoh atau pemain film.

Tabel 1. Hubungan Manusia dengan Tuhan sang pencipta.

\begin{tabular}{|l|l|}
\hline \multicolumn{1}{|c|}{ Signified } & \multicolumn{1}{|c|}{ Signifier } \\
\hline $\begin{array}{l}\text { 1. Hubungan manusia dengan Tuhan sang } \\
\text { pencipta. }\end{array}$ & $\begin{array}{l}\text { Ekspresi yang sedang dilakukan } \\
\text { ketika Kevin sedang berdoa } \\
\text { sebelum makan. }\end{array}$ \\
\hline
\end{tabular}




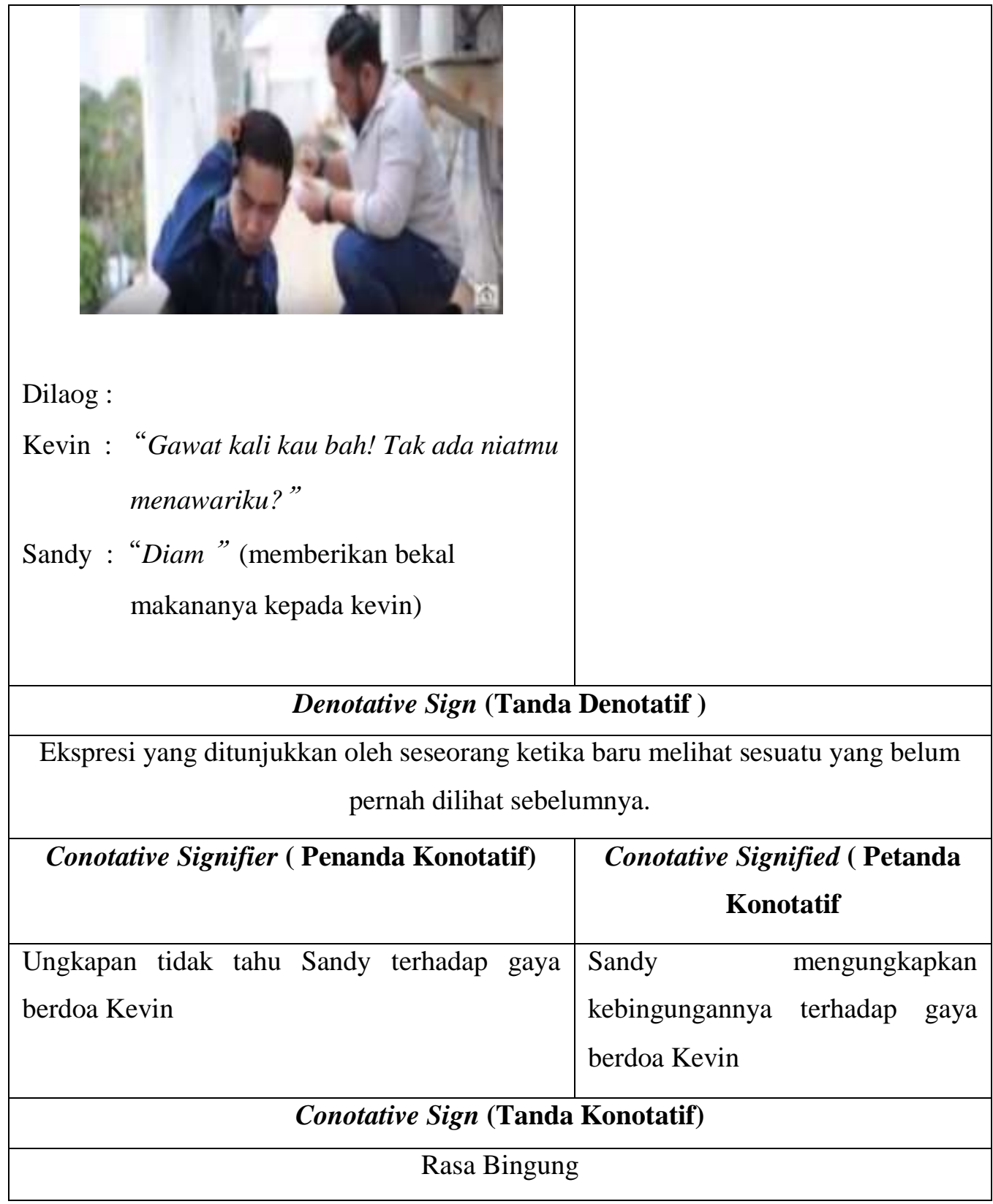

Tabel 1 telah menjelaskan mengenai hubungkait antara tanda dan penanda berdasrkan Peta Tanda Roland Barthes.Adapun maknadenotatif dan konotatif dari table 1 adalah sebagai berikut.

\section{III.1. Makna Denotatif}

Adegan pada scene 27 Menit lewat 58 detik memperlihatkan Sandy pergi ke balkon kampus, setelah Aldo dan teman-temanya mengerjai Sandy ketika sedang makan siang. Akhirnya Sandy lari dan menuju balkon kampus, sandy bertemu dengan Kelvin seorang pemuda Kristen, Sandy pun berkenalan dengan Kevin, setelah berkenalan Sandy pun duduk untuk melanjutkan makan siangnya bersama Kevin.

III.2. Makna Konotatif

Adegan pada scene 27 Menit lewat 58 detik memperlihatkan Sandy sedang memberikan bekal makananya kepada Kevin, untuk makan bersama-sama. 


\section{EXT. KAMPUS. BALKON - DAY}

Gawat kali kau bah! Tak ada niatmu menawariku?

Pertanyaan tersebut menekankan kepada Sandy, ketika Sandy membuka bekal makanan tidak menawari Kevin yang ada disebelahnya. Teknik medium shoot dipergunakan untuk memperlihatkan kondisi sekitar bawah lutut sampai atas serta memperlihatkan kondisi sekitar Sandy dan Kevin yang sedang berada di balkon kampus.Menurut H.M.Y. Biran mengatakan bahwa:

Medium shoot adalah Intermediate shoot karena terletak antara Long Shoot dan close up. Pemain direkam dari batas lutut, keatas, atau sedikit dibawah pinggang (Biran, 1987: 36).

\section{PENUTUP}

Berdasarkan hasil pada pembahasan yang merupakan analisis dari pesan moral dengan menggunakan teori semiotika Roland Barthes, peneliti menemukan dan mendapatka hasil yang telah peneliti analisis pada film Jangan baca pancasila karya Rafdi Akbar, bahwa pesan moral yang terdapat dalam film Jangan Baca Pancasila,dilihat dari sisi pandang kehidupan dengan melalui tanda yang muncul, dan ditampilkan baik itu secara visual maupun verbal pada setiapscene, terkandung beberapa pesan moral yaituadanya hubungan manusia dengan tuhan sang pencipta, hubungan manusia dengan manusia, dan adanya hubungan manusia dengan lingkungan.

\section{DAFTAR PUSTAKA}

[1] Budiningsih, Asri. (2004). Pembelajaran Moral. Jakarta: Rineka Cipta.

[2] Effendy, Erdianto, Erdianya. (2004). Komunikasi Massa. Bandung; PT. Remaja Rosda Karya.

[3] Irawanto, Budi. (1999). Film Ideologi dan Militer. Yogyakarta: Media Presindo.

[4]. Kriyantono, Rachmat. 2010. Teknik praktis riset komunikasi: disertai contoh praktis riset media, public relation, advertising, komunikasi organisaso, komunikasi pemasaran. Jakarta: Kencana

[5] Mc. Qual, Dennis. (2005). Teori Komunikasi Massa. Jakarta: Erlangga.

[6] Moeloeng, Lexy J. 2004. Metodologi Penelitian Kualitatif. Bandung: PT. Remaja Rosda Karya.

[7] Nawiroh, Vera. (2014). Semiotika Dalam Riset Komunikasi. Bogor: Ghalia

[10] Nurgiyantoro, Burhan. (2009). Teori Pengkajian Fiksi.Yogyakarta: UGM

[11] Pratista, Himawan. (2008). Memahami Film. Yogyakarta: Homerian Pustaka.

[12] Rokhayah. (2015). Pesan Moral Membentuk Keluarga Sakinah Dalam Film "Habiebi dan Ainun “ Karya Faozan Rizal”, Skripsi Universitas Walisongo Fakultas Dakwah Dan Komunikasi Jurusan Komunikasi dan Penyiaran Islam. [Online] Tersedia : http://eprints.walisongo.ac.id/4941/1/101211029.pdf (Download 4 April 2018).

[13] Suseno, Magnis. (1987). Etika dan Masalah-Masalah Pokok Filsafat Moral. Yogyakarta: Kanisius. 
[14] Sobur, Alex. [2009]. Semiotika Komunikasi. Bandung: Remaja Rosdakarya.

[15] Wibowo Andri Priyatna. 2010. Amazing Autism. Jakarta: PT. Elex Media Komputindo.

[16] Yuwono, J. (2009). Memahami Anak Autistik: Kajian Teoritik dan Empirik. Yogyakarta: Alfabeta.

[17] Weisarkurnai, B. F., \& Nasution, B. (2017). Representasi Pesan Moral dalam Film Rudy Habibie Karya Hanung Bramantyo (Analisis Semiotika Roland Barthes). Jurnal Online Mahasiswa Fakultas Ilmu Sosial dan Ilmu Politik Universitas Riau, 4(1), 1-14.

[18] Nisa, I., (2014). Analisis Semiotika Pesan Moral Dalam Film Jokowi, Skripsi Universitas Islam Syarif Hidayatullah Fakultas Ilmu Dakwah Dan Ilmu Komunikasi Jurusan Komunikasi dan Penyiaran Islam. [Online] Tersedia: http://repository.uinjkt.ac.id/dspace/bitstream/123456789/26866/1/ISHMATUN\%20NIS A-FDK.pdf (Download 4 April 2018)

[19] Ilmu Komunikasi Universitas Mulawarman. 2014. eJournal Volume 2, Nomor 2, 280-281. 